\title{
Photosynthetic responses of understory savanna plants: Implications for plant persistence in savannas under tree encroachment
}

\author{
Davi Rodrigo Rossatto ${ }^{\mathrm{a}, *}$, Paola Eduarda de Araújo ${ }^{\mathrm{a}}$, Bianca Helena Porfírio da Silva ${ }^{\mathrm{a}}$, \\ Augusto César Franco ${ }^{\mathrm{b}}$ \\ ${ }^{a}$ Departamento de Biologia, Faculdade de Ciências Agrárias e Veterinárias, Univ. Estadual Paulista, UNESP Campus de Jaboticabal, Via de Acesso Prof. Paulo Donato \\ Castellane S/N, Vila Industrial, 14884-900, Jaboticabal, SP, Brazil \\ b Departamento de Botânica, Instituto de Ciências Biológicas, Universidade de Brasília, Campus Darcy Ribeiro, Asa Norte, 70910-900, Brasília, DF, Brazil
}

\section{A R T I C L E I N F O}

Edited by Hermann Heilmeier

Keywords:

Cerrado

Encroachment

Leaf functional traits

Leaf gas exchange

Leaf pigments

Shade tolerance

\begin{abstract}
A B S T R A C T
Savannas are ecosystems where plants are expected to have leaf-level adaptations conferring tolerance to high irradiances, which characterizes this type of open canopy vegetation. The neotropical savannas of Brazil (Cerrado) harbour a large diversity of heliophilous herbaceous species, which are threatened by the current invasion of those open canopy habitats by forest trees, increasing tree density and canopy cover, thereby strongly reducing light availability. In this study, we measured leaf pigment concentrations, specific leaf area and light response curves of photosynthesis to determine whether herbaceous species of open savanna habitats were less tolerant to shade than the ones that were more characteristic of forested savanna. Relative to species of forested savannas, herbaceous species of open savannas had heavier leaves with higher concentration of carotenoids. They also achieved higher photosynthetic rates, reaching light compensation and saturation at higher irradiances. Based on measurements of light compensation points and of prevailing irradiances in forested savannas, leaves of most herbaceous species of more open savannas would be strongly light-limited in sites with a dense woody layer. In summary, we provide evidence that forest tree encroachment of savannas would select for leaf trait combinations in the understory vegetation that would favor shade tolerance and, depending on the degree of leaf acclimatization to shade of individual species, could strongly constrain persistence of the current understory vegetation.
\end{abstract}

\section{Introduction}

Light can be posed as the most fundamental resource for establishment, growth and persistence of plants in a variety of vegetation types (Belsky, 1994; Walters and Reich, 1996; Poorter and Kitajima, 2007). The quality and quantity of this resource depend on environmental and biological factors, such as time of the year and vegetation structure (Denslow and Guzman, 2000; Peterson et al., 2007). In particular, the physical structure of the standing vegetation generates a vertical gradient of light availability and spatial heterogeneity on understory light regimes, strongly affecting seedling establishment and the growth of the understory vegetation. In tropical forests, the high density and height of trees with large and dense crowns restrict the amount of available light for understory plants to perform photosynthesis (Poorter, 1999). In contrast, seedlings and the understory vegetation are exposed to much higher irradiances in tropical savannas, given the scattered pattern of the woody vegetation, which is characterized by small-stature trees with open narrow crowns (Ludwig et al., 2004; Hoffmann et al., 2005).

Because of the contrasting light availabilities, distinct environmental filters operate in forests and savannas, selecting for divergent structural and physiological leaf traits (Kitajima, 1994; Givnish et al., 2004; Kotowski and Diggelen, 2004; Poorter, 2009). In forests, the sharp variation of irradiance within the canopy results in a vertical gradient of light-use strategies at the leaf level, where trees that reach the upper canopy layers have thicker leaves with higher photosynthetic capacity and mechanisms of protection against high irradiances (Thompson et al., 1992; Santiago and Wright, 2007). In turn, light is a limiting resource for understory plants. They tend to have thinner leaves with large blades and high chlorophyll concentrations as adaptations to increase the capture of diffuse light (Valladares et al., 2002). Light availability to understory plants in savannas is more variable than in forests because of the large spatial variation in canopy cover and tree density (Scholes and Archer, 1997; Hoffmann et al., 2005). However,

\footnotetext{
* Corresponding author.

E-mail addresses: drrossatto@gmail.com,drrossatto@fcav.unesp.br (D.R. Rossatto).
} 
the open nature of the savanna vegetation implies that the majority of the understory plants have to persist under higher irradiances in comparison to those thriving in the forest understory (Ludwig et al., 2004; Pinheiro et al., 2016). This situation may have selected for a suite of leaf traits and photosynthetic responses to cope with high irradiances, such as smaller leaf area, higher photosynthetic capacity and higher concentration of photoprotective pigments (Franco et al., 2007; Goulart et al., 2011) in comparison to understory plants in forested environments, where shade tolerance is vital (Prior et al., 2003; Lüttge, 2008).

Understanding functional responses of savanna plants concerning light availability is of outmost importance because open humid savannas can undergo transition to closed canopy woodlands (forested savanna) or forests in the absence of fire (Silva et al., 2008; Pinheiro and Durigan, 2009; Murphy and Bowman, 2012; Hoffmann et al., 2012a; Stevens et al., 2017). This is particularly common in the seasonal Neotropics, where vegetation mosaics of forests and savannas characterize the landscape, and when fire is suppressed, there is a high recruitment of typical forest species in savanna sites (Hoffmann et al., 2012a). This increased recruitment of forest species, with their denser and larger canopies, strongly modifies the savanna environment (Hoffmann et al., 2012b). In particular, canopy closure reduces light availability for understory plants, which can select for suites of leaf traits promoting efficient light energy capture while minimizing carbon losses (low respiration rates) under low-light (Valladares et al., 2012). If typical savanna understory plants are in fact light demanding species, they might not be able to maintain a positive leaf carbon balance following canopy closure. Canopy closure can therefore affect species persistence in the savanna understory, resulting in changes in species richness and composition (McGuire et al., 2001; Brudvig, 2010; Pinheiro et al., 2016).

Here we performed a comparative study of photosynthetic traits in a range of non-arboreal species that are either exclusive from typical open savannas or of forested savannas to understand their role in plant persistence under encroachment. Since closed canopy environments are subjected to a strong light filter (low light availability) we expected species from forested savanna to show traits related to optimizing lightharvesting efficiency and net $\mathrm{CO}_{2}$ assimilation in low light while minimizing $\mathrm{CO}_{2}$ losses (lower dark respiration rates). In turn, typical savanna species would have been selected to prioritize carbon gain and mechanisms to safe dissipation of potentially harmful excess light energy, with leaves with higher carotenoid concentrations, higher rates of net $\mathrm{CO}_{2}$ assimilation and dark respiration per unit leaf area.

\section{Material and methods}

\subsection{Study site}

Our study was performed at the Assis Ecological Station (AES), located at Assis municipality, São Paulo state, Brazil ( $22^{\circ} 35^{\prime} 51.36^{\prime \prime} \mathrm{S}, 50^{\circ}$ $22^{\prime} 26.68$ " W) during the wet season of 2016. AES is located at $500-588 \mathrm{~m}$ above sea level, where the climate is a transition between Cwa and Cfa according to Köppen classification. The rainy season extends from September to May, when monthly rainfall exceeds $70 \mathrm{~mm}$. The dry season spans from June to August. Fire prevention and suppression measurements have excluded fire from AES for the past 50 years, which has resulted in forest tree encroachment of many savanna sites and concomitant increase of canopy cover of the woody layer (Pinheiro and Durigan, 2009; Pinheiro et al., 2016).

\subsection{Species selection and environmental conditions}

To study structural and photosynthesis-related leaf characteristics we selected 18 non-arboreal species (herbs, vines, sub-shrubs and shrubs) exclusively found at typical or forested savanna at our study site (Table 1), according to a previous field survey (Pinheiro et al., 2016). All data collection was performed on the same individuals. We sampled
Table 1

Studies species, their families and their habit in typical and forested savanna vegetation.

\begin{tabular}{|c|c|c|c|}
\hline Vegetation & Family & Species & Habit \\
\hline Typical & Anacardiaceae & Anacardium humile A. St.-Hil. & Subshrub \\
\hline Typical & Asteraceae & $\begin{array}{l}\text { Lepidaploa aurea (Mart. ex DC.) H. } \\
\text { Rob. }\end{array}$ & Subshrub \\
\hline Typical & Euphorbiaceae & Croton campestris A.St.-Hil. & Herb \\
\hline Typical & Fabaceae & $\begin{array}{l}\text { Senna rugosa (G.Don) H.S.Irwin \& } \\
\text { Barneby }\end{array}$ & Shrub \\
\hline Typical & Lamiaceae & Peltodon tomentosus Pohl. & Herb \\
\hline Typical & Malvaceae & $\begin{array}{l}\text { Peltaea polymorpha (A. St.-Hil.) } \\
\text { Krapov. \& Cristóbal }\end{array}$ & Herb \\
\hline Typical & Melastomataceae & Miconia fallax DC. & Shrub \\
\hline Typical & Menispermaceae & Cissampelos ovalifolia DC. & Herb \\
\hline Typical & Poaceae & $\begin{array}{l}\text { Axonopus pressus (Nees ex Steud.) } \\
\text { Parodi }\end{array}$ & Herb \\
\hline Forested & Dilleniaceae & Doliocarpus dentatus (Aubl.) Standl. & Vine \\
\hline Forested & Malpighiaceae & $\begin{array}{l}\text { Mascagnia cordifolia (A. Juss.) } \\
\text { Griseb. }\end{array}$ & Vine \\
\hline Forested & Melastomataceae & Leandra melastomoides Raddi & Shrub \\
\hline Forested & Melastomataceae & Leandra lacunosa Cogn. & Shrub \\
\hline Forested & Melastomataceae & Miconia paucidens DC & Subshrub \\
\hline Forested & Poaceae & Panicum sellowii Nees & Herb \\
\hline Forested & Rubiaceae & $\begin{array}{l}\text { Coccocypselum lanceolatum (Ruiz } \\
\text { \&Pav.) Pers. }\end{array}$ & Herb \\
\hline Forested & Rubiaceae & Palicourea marcgravii A. St.-Hil. & Shrub \\
\hline Forested & Rubiaceae & $\begin{array}{l}\text { Psychotria hoffmannseggiana (Willd. } \\
\text { ex Schult.) Müll.Arg. }\end{array}$ & Subshrub \\
\hline
\end{tabular}

9 species growing exclusively in typical savanna (TS) vegetation: a discontinuous woody layer over a continuous herbaceous-grass stratum, with a tree layer leaf area index (LAI) of $0.96 \pm 0.05 \mathrm{~m}^{2} \mathrm{~m}^{-2}$ (mean \pm SE) and PPFD of $597 \pm 197 \mu \mathrm{mol} \mathrm{m}^{-2} \mathrm{~s}^{-1}$ at the typical maximum height of the understory canopy $(70 \mathrm{~cm}$ above soil surface). We also sampled 9 species exclusively found in forested savanna (FS): previously a typical savanna that is currently covered with a continuous species-rich tree layer with few species in the groundlayer, where tree layer LAI was $1.90 \pm 0.12 \mathrm{~m}^{2} \mathrm{~m}^{-2}$ and PPFD of $32 \pm 2 \mu \mathrm{mol} \mathrm{m}{ }^{-2} \mathrm{~s}^{-1}$ (LAI values retrieved from Pinheiro et al., 2016). PPFD values were obtained from measurements in 30 different locations (at least $800 \mathrm{~m}$ apart) in a typical savanna and 30 different locations in a forested savanna. PPFD measurements were taken at $70 \mathrm{~cm}$ height from the soil surface with a CI-110-24P-ID plant canopy imager (CID Bioscience, Camas, WA, USA) and collected every $30 \mathrm{~min}$ in a period of $4 \mathrm{~h}$ in the morning between 08:00 and 12:00 $\mathrm{h}$ during 5 sunny days, without rain or clouds, in November 2016.

\subsection{Leaf structure and leaf pigments}

As a surrogate of leaf structure, we measured specific leaf area $\left(\mathrm{cm}^{2} \mathrm{~g}^{-1}\right)$ in one healthy and expanded leaf from the second or third node of each individual (3 individuals per species). Specific leaf area (SLA) was calculated as the ratio of leaf area (obtained from the Image $\mathrm{J}$ free software) to leaf dry mass (dried at $70^{\circ} \mathrm{C}$ for $48 \mathrm{~h}$ and weighed on a precision scale $( \pm 0.0001 \mathrm{~g})$ ).

We determined the photosynthetic pigment concentration (chlorophyll $a$ (chl $a$ ), chlorophyll $b$ (chl $b$ ), total carotenoids (car)) by collecting one leaf disc $\left(1 \mathrm{~cm}^{2}\right)$ per individual, three individuals per species, between the mid-vein and the leaf margin, in adult healthy leaves. The discs were stored in $2 \mathrm{~mL}$ tubes of amber color which contained DMF (N,N-dimethylformamide) (Porra et al., 1989). The tubes were kept in the dark at $4{ }^{\circ} \mathrm{C}$ for a period of $48 \mathrm{~h}$. The samples were then analyzed in a spectrophotometer (Quimis Q898DRM) to determine the absorbance at wavelengths of 647,664 and $480 \mathrm{~nm}$. The absorbance values were used to calculate the concentrations of chl $a$, chl $b$ and car (in $\mu \mathrm{g} \mathrm{cm}^{-2}$ ) according to Wellburn (1994). Total chlorophyll (cht) was obtained as the sum of chlorophyll $a$ and chlorophyll $b$. We also calculated the chlorophyll $a: b$ ratio (cha:chb). 


\subsection{Light response curves}

We used an LcProSD (ADC BioScientific Ltd., Hoddesdon, UK) photosynthesis measurement system for gas exchange light curves. Healthy leaves (one leaf per individual), from the second and third node, without senescence and damage signals, were placed in the LcProSD broad chamber $\left(6 \mathrm{~cm}^{2}\right)$, at ambient $\mathrm{CO}_{2}$ concentrations $\left(398.17 \pm 2.13 \mu \mathrm{Ll}^{-1}\right)$ and relative humidity $(\approx 65 \%)$, but controlling the temperature $\left(26 \pm 1.6^{\circ} \mathrm{C}\right)$. We used 16 photosynthetic photon flux density (PPFD) levels generated by a blue-red led light source in the following order: 1800,1600, 1400, 1200, 1000, 800, 600, 400, 200, $160,120,80,40,20,10$ and $0 \mu \mathrm{mol} \mathrm{m}^{-2} \mathrm{~s}^{-1}$. Area-based net photosynthetic rate $\left(\mathrm{A}_{\mathrm{CO} 2}\right)$ and stomatal conductance $\left(\mathrm{g}_{\mathrm{s}}\right)$ at each PPFD were stored once those values had stabilized (around $6 \mathrm{~min}$ ). Leaf temperature was maintained at $26.5 \pm 1.6^{\circ} \mathrm{C}$. Leaf respiration $\left(\mathrm{R}_{\mathrm{D}}\right)$ was measured by keeping the leaves for ten minutes in the dark by covering the leaf chamber with aluminum foil. Measurements were taken during the morning hours (9:00-11:30 h).

A non-rectangular hyperbole was fitted to the data (area-based $\mathrm{CO}_{2}$ assimilation $\left(\mathrm{A}_{\mathrm{CO} 2}\right)$ as a function of PPFD) following Thornley (1976) and using the algorithms provided by Lobo et al. (2013). Based on the fitted curves, we extracted values of $\mathrm{A}_{\max }$ - the maximum area-based rate of light-saturated $\mathrm{A}_{\mathrm{CO} 2}\left[\mu \mathrm{mol}\left(\mathrm{CO}_{2}\right) \mathrm{m}^{-2} \mathrm{~s}^{-1}\right]$, the light-compensation point (LCP) (PPFD where $\mathrm{A}_{\mathrm{CO} 2}=0$ ), and the light-saturation point (LSP) (Prioul and Chartier, 1977). Apparent quantum yield (AQY) was calculated as the initial slope of the light response curve. The convexity coefficient (CC -bending rate of the photosynthetic light response curve) was obtained from the non-rectangular hyperbole fitted to the data.

\subsection{Statistical analysis}

Our focus was on comparing species exclusively found on open savanna sites with those of forested savanna sites. In this regard we used the mean values provided for each species in a multivariate analysis of variance (MANOVA), followed by F-tests to test for differences in leaf morphological and physiological characteristics between typical and forested savanna herbaceous plants $(\alpha=0.05)$. Prior to the analysis we checked for data homoscedasticity, which was fulfilled (Levenés test $\mathrm{F}<2.12, \mathrm{P}>0.08)$.

\section{Results}

\subsection{Leaf morphology and pigments}

FS and TS species differed (MANOVA Wilks $\lambda=0.152, \mathrm{~F}_{5}=12.25$, $\mathrm{P}<0.01$ ) in specific leaf area and leaf pigment concentrations (Fig. 1). TS species had leaves with lower $\left(\mathrm{F}_{1,15}=29.28, \mathrm{P}<0.01\right)$ specific leaf

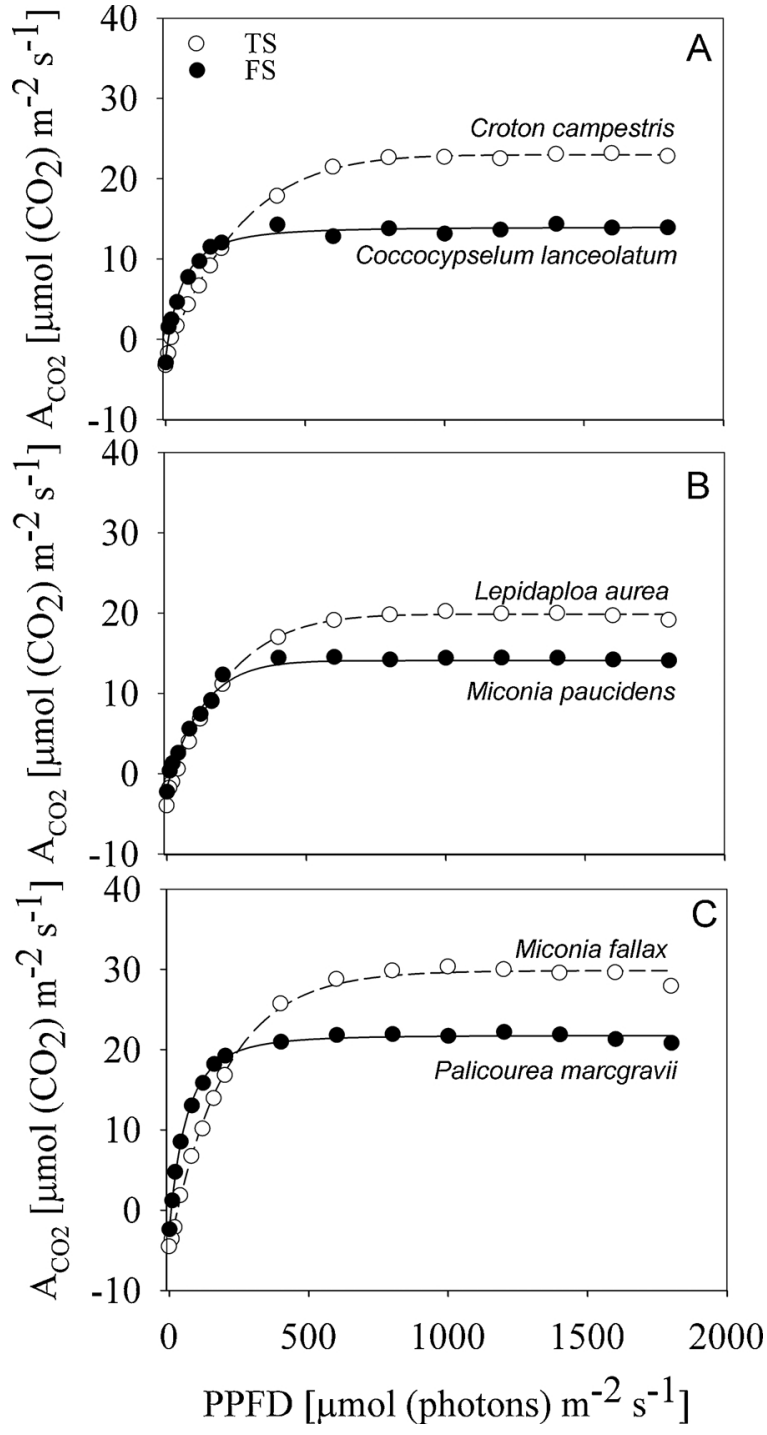

Fig. 2. $\mathrm{CO}_{2}$ assimilation rates $\left(\mathrm{A}_{\mathrm{CO} 2}\right)$ vs. photosynthetic photon flux density (PPFD) in (A) herbs, (B) subshrubs and (C) shrubs. White circles: typical savanna species (TS); black circles: forested savanna species (FS).

area (130.94 vs $267.73 \mathrm{~cm}^{2} \mathrm{~g}^{-1}$ ). In terms of pigments, there were significant $\left(\mathrm{F}_{1,15}>5.20, \mathrm{P}<0.05\right)$ differences for chlorophyll $b$, total carotenoids and chlorophyll $a: b$ ratio (Fig. 1). Forested savanna species had leaves with higher concentrations of chlorophyll $b$ (16.20 vs
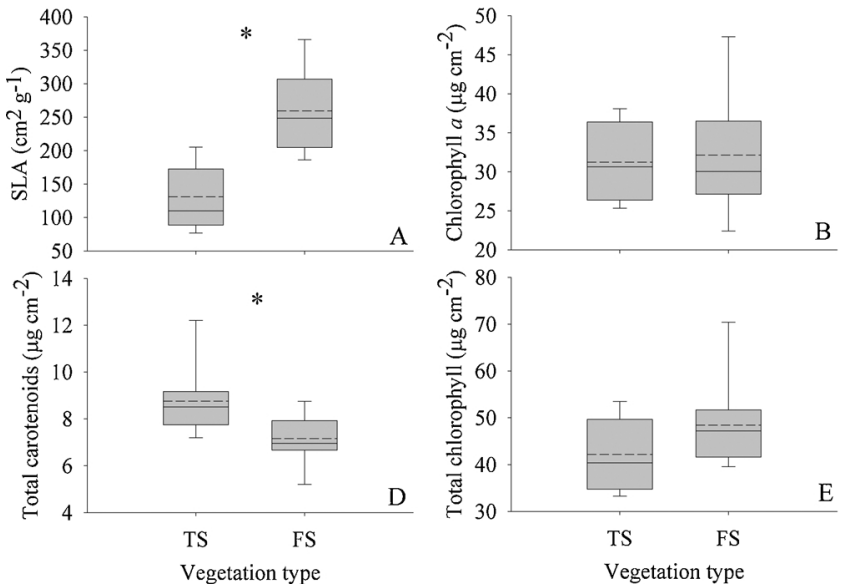

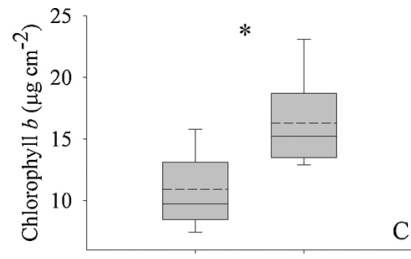

C

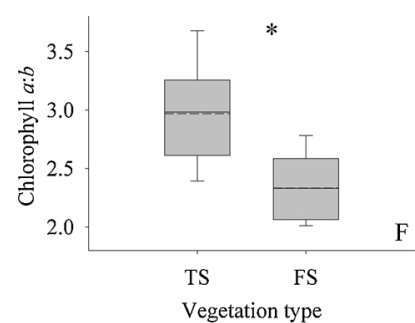

Fig. 1. Box plots (5th-95th percentile) of leaf attributes related to light environment in typical (TS) and forested savanna (FS) understory species. (A) specific leaf area (SLA); (B) chlorophyll $a$; (C) chlorophyll $b$; (D) total carotenoids; (E) total chlorophyll and (F) chlorophyll a:b ratio. Solid lines: median; dashed lines: mean. * indicates significant differences according to the F-test $(P<0.05)$. 
Table 2

Photosynthetic parameters studied for typical savanna and forested savanna conditions. Means followed by standard error of the mean $(n=10)$. Different letters on the same line denote significant differences according to an F test $(\alpha=0.05)$. SLA - specific leaf area; $A_{\text {max }}$ - maximum area-based rate of light-saturated $\mathrm{CO}_{2}$ assimilation; $R_{D}$ - leaf dark respiration; LCP - light compensation point; LSP - light saturation point; AQY - apparent quantum yield; CC - convexity coefficient.

\begin{tabular}{lll}
\hline Parameters & Typical Savanna & Forested Savanna \\
\hline SLA $\left[\mathrm{cm}^{2} \mathrm{~g}^{-1}\right]$ & $129.05 \pm 14.17 \mathrm{~b}$ & $252.77 \pm 23.25 \mathrm{a}$ \\
$\mathrm{A}_{\max }\left[\mu \mathrm{mol}\left(\mathrm{CO}_{2}\right) \mathrm{m}^{-2} \mathrm{~s}^{-1}\right]$ & $24.91 \pm 1.49 \mathrm{a}$ & $18.56 \pm 1.68 \mathrm{~b}$ \\
$\mathrm{R}_{\mathrm{D}}\left[\mu \mathrm{mol}\left(\mathrm{CO}_{2}\right) \mathrm{m}^{-2} \mathrm{~s}^{-1}\right]$ & $-3.96 \pm 0.33 \mathrm{~b}$ & $-1.97 \pm 0.25 \mathrm{a}$ \\
$\mathrm{LCP}\left[\mu \mathrm{mol}(\mathrm{photons}) \mathrm{m}^{-2} \mathrm{~s}^{-1}\right]$ & $35.78 \pm 1.07 \mathrm{a}$ & $6.44 \pm 1.06 \mathrm{~b}$ \\
$\mathrm{LSP}\left[\mu \mathrm{mol}\left(\mathrm{photons}^{-1} \mathrm{~m}^{-2} \mathrm{~s}^{-1}\right]\right.$ & $391.23 \pm 28.55 \mathrm{a}$ & $166.62 \pm 15.33 \mathrm{~b}$ \\
$\mathrm{AQY}\left[\mu \mathrm{mol}\left(\mathrm{CO}_{2}\right) \mu \mathrm{mol}^{-1}\right.$ (photons)] & $0.071 \pm 0.004 \mathrm{~b}$ & $0.091 \pm 0.001 \mathrm{a}$ \\
$\mathrm{CC}$ & $0.808 \pm 0.031 \mathrm{a}$ & $0.776 \pm 0.058 \mathrm{a}$ \\
\hline
\end{tabular}

$10.91 \mu \mathrm{g} \mathrm{cm}^{-2}$ ), but with lower concentrations of total carotenoids (7.24 vs $8.80 \mu \mathrm{g} \mathrm{cm}^{-2}$ ) and lower chlorophyll $a: b$ ratio (2.37 vs 2.96 ). No differences $\left(\mathrm{F}_{1,15}<1.00, \mathrm{P}>0.30\right)$ were found for chlorophyll $a$ (31.24 vs $31.90 \mu \mathrm{g} \mathrm{cm}^{-2}$ ) or total chlorophyll (41.15 vs $48.11 \mu \mathrm{g} . \mathrm{cm}^{-2}$ ) concentrations.

\subsection{Light response curves}

FS and TS species showed clear differences in the shape of the light response curves, and hence of the underlying photosynthesis processes (Fig. 2). $\mathrm{A}_{\mathrm{CO} 2}$ in FS species increased faster than in TS species at lower light levels but approached saturation at lower light levels. Overall $\mathrm{A}_{\mathrm{CO} 2}$ was higher for FS species at low PPFD, but lower at high PPFD (Fig. 2). There were also clear differences between FS and TS species in the photosynthetic parameters derived from the light response curves (MANOVA Wilks $\lambda=0.147, \mathrm{~F}_{6}=10.59, \mathrm{P}<0.01$ ). The higher apparent quantum yield of FS species indicates higher light use efficiency for fixing $\mathrm{CO}_{2}$ at low PPFD as compared to TS species (Table 2). They also reached the light compensation point (LCP) at lower PPFD. In contrast, TS species had higher values of maximum $\mathrm{A}_{\mathrm{CO} 2}\left(\mathrm{~A}_{\max }\right)$ and dark respiration $\left(R_{D}\right)$, and reached saturation at higher PPFD, while there were no differences between FS and TS species for the convexity coefficient (Table 2).

TS species had a high variation in LCP and most species reached light compensation at PPFD values that were above the mean PPFD incident on the soil surface of a forested savanna, about $32 \mu \mathrm{mol} \mathrm{m}^{-2} \mathrm{~s}^{-1}$ (Fig. 3). FS species were more constrained in the range of LCP values; however, all of them reached light compensation at PPFDs well below $32 \mu \mathrm{mol} \mathrm{m} \mathrm{m}^{-2} \mathrm{~s}^{-1}$.

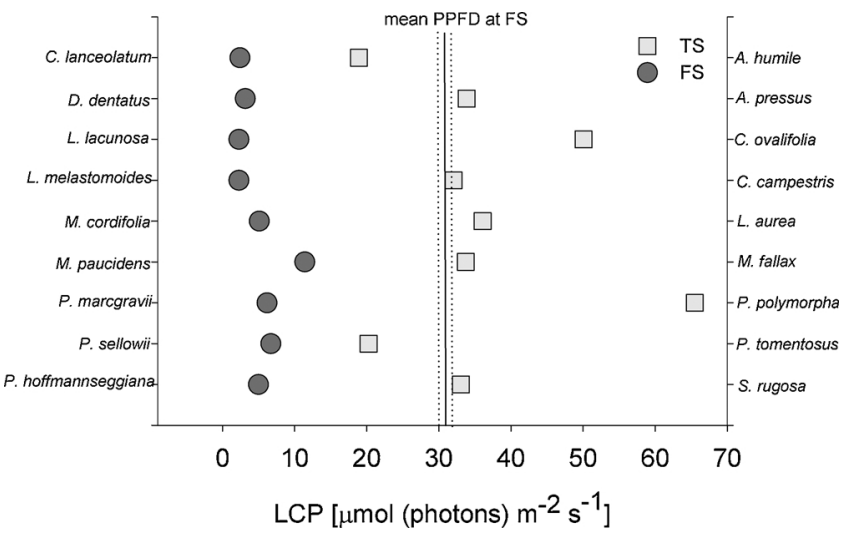

Fig. 3. Individual light compensation points (LCP) for typical (TS) and forested (FS) savanna species in relation to the mean value of photosynthetic photon flux density (PPFD, in $\mu \mathrm{mol} \mathrm{m} \mathrm{m}^{-2} \mathrm{~s}^{-1}$ ) incident on a forested savanna understory. The vertical solid line corresponds to the mean PPFD of $32 \mu \mathrm{mol} \mathrm{m}{ }^{-2} \mathrm{~s}^{-1}$ measured at the soil surface of a forested savanna (see Material and Methods) while the dotted lines represent the standard deviation.

\section{Discussion}

Our expectations were corroborated, since typical and forested savanna plants differed for the majority of the studied traits (Table 2 and Fig. 1), providing evidence for distinct leaf functional typologies related to the prevailing irradiance levels on their environment of occurrence. Plants that occurred exclusively in the understory of encroached environments (high canopy cover and lower irradiances) had leaves with high specific leaf area, elevated chlorophyll $b$ concentration and lower photosynthetic capacity. In contrast, plants from open canopy savannas had thicker leaves with higher photosynthetic capacity and higher concentration of carotenoids. These responses were previously reported for tree species thriving under sun and shade conditions (Givnish, 1988) as well for tropical forest trees and some species of understory vegetation (Chazdon and Pearcy, 1986; Valladares and Niinemets, 2008), but rarely reported for understory tropical savanna plants.

The lower SLA and high carotenoid concentration of TS species can be posed as an indicator of protection mechanisms against the elevated irradiances prevailing on these more open savanna habitats (Franco and Lüttge, 2002; Franco et al., 2007). The lower values of SLA of TS species is the result of high level of investment in tissue thickness, closely packed mesophyll cells and in suberized and lignified structures (Bieras and Sajo, 2009; Pinheiro et al., 2017). In contrast, understory FS plants showed thinner leaves with high concentrations of chlorophyll $b$ on a leaf area basis. Preferential investment in light capture is an important strategy to thrive under low light availability (Poorter and Bongers, 2006), and their photosynthetic patterns were also in accordance with what one would expect for shade tolerant species: low $A_{\max }$ coupled with low light compensation and saturation points and low leaf respiration (Valladares et al., 2000).

Our analysis of the photosynthetic light response curves contributes to our understanding of the causes related to the disappearance of typical savanna understory plants following forest tree encroachment (Durigan and Ratter, 2006; Abreu et al., 2017). Their disappearance may be the result of carbon starvation given the strong decrease in light availability in savannas undergoing forest encroachment. Under forest savanna conditions, average values of PPFD available for understory plants are around $32 \mu \mathrm{mol} \mathrm{m} \mathrm{m}^{-2} \mathrm{~s}^{-1}$. These low light levels would probably lead to negative carbon balance in leaves for the majority of typical savanna understory plants, which required, on average, $36 \mu \mathrm{mol}$ photons $\mathrm{m}^{-2} \mathrm{~s}^{-1}$ just to reach the light compensation point for instantaneous measurements of leaf-level photosynthesis (Table 2).

In fact, seven out of nine TS species would not be capable to achieve their light compensation points under dense tree encroachment conditions. However, these irradiance levels are more than enough to promote positive carbon gain at the leaf level of all studied forested savanna species (where average LCP is around $6 \mu \mathrm{mol} \mathrm{m} \mathrm{m}^{-2} \mathrm{~s}^{-1}$ ) (Fig. 3). One can argue that phenotypic plasticity could allow the persistence of typical savanna plants under encroached conditions, as many woody species from the Cerrado are reported to occur under distinct irradiance levels (Lemos Filho et al., 2008; Bedetti et al., 2011). Despite further work is required to unravel the potential of understory savanna species to acclimate to different irradiance conditions, 8 out of 9 of the studied species from typical savanna were never reported to occur under forested conditions (Mendonça et al., 2008; Pinheiro et al., 2016). From our list of studied species, Anacardium humile is the only one reported to occur in forested formations (Mendonça et al., 2008), exactly the species from typical savanna that has the lowest compensation point in comparison with other species (Fig. 3). Although it is clear that encroachment affects the $\mathrm{C}$ balance at the leaf level, studies at the whole plant level are necessary to clearly understand plant $\mathrm{C}$ balance and consequently survival, growth and persistence in such encroached savannas.

Nutrients and water availability may also play a role on species persistence, since they also change according with encroachment condition (Eldridge et al., 2011). Rossatto and Rigobelo (2016) showed 
increases in soil $\mathrm{P}$, carbon matter and microbial activity under forested savanna, and Pinheiro et al. (2016) showed higher soil water availability in forested savanna than in typical savanna. Such changes may act together on plant establishment (especially germination and growth); however, we argue that light availability is the most immediate factor since canopy cover can be achieved more quickly than biogeochemical changes and can strongly affect the carbon balance of the already established plants in the understory.

One manner to restore conditions for persistence of typical savanna plants is to use fire as a management tool to create habitat heterogeneity that would allow the maintenance of populations of understory species with different levels of shade tolerance. However, the use of fire as a means of management is not always feasible since it demands a very strict control, high investment in trained staff, infrastructure, and equipment and carries inherent risks, as fires can escape or produce hazardous smoke if not managed correctly (Durigan and Ratter, 2016). Taken the photosynthetic strategies shown here, a potential alternative would be the partial cutting of the woody layer to create gaps, which would allow more light to enter these encroached areas leading to establishment/growth/resprout of heliophyllous herbaceous species (Beaudet et al., 2004; Lemenih et al., 2004). The cut biomass, however, should be removed since it could lead to build up of great amounts of fuel that could lead to fires of catastrophic proportion (Govender et al., 2006).

Our results have an impact on our understanding of possible plant community changes in Cerrado areas given the observed patterns of global change reported for savannas (Franco et al., 2014; Stevens et al., 2017). We provide strong evidence that forest tree encroachment of savannas will affect persistence of typical savanna understory species, due to their higher light requirements to maintain positive carbon balance. This would bring not only changes in the community structure and composition of the understory vegetation, but it could also affect ecosystem aspects related to litter production and nutrient cycling.

\section{Acknowledgments}

This study was conducted with financial support from BIOTA FAPESP (Proc. 2013/18049-6, 2015/21857-2), FAP-DF (№ FAPDF: 1078/2016), PIBIC-UNESP and PQ-CNPq (301589/2015-1; 308182/ 2015-4).

\section{References}

Abreu, R.C.R., Hoffmann, W.A., Vasconcelos, H., Pilon, N., Rossatto, D.R., Durigan, G., 2017. The biodiversity cost of carbon sequestration in tropical savanna. Sci. Adv. e1701284.

Beaudet, M., Messier, C., Leduc, A., 2004. Understorey light profiles in temperate deciduous forests: recovery process following selection cutting. J. Ecol. 92, 328-338.

Bedetti, C.S., Aguiar, D.B., Jannuzzi, M.C., Moura, M.Z.D., Silveira, F.A.O., 2011. Abiotic factors modulate phenotypic plasticity in an apomictic shrub [Miconia albicans (SW.) Triana] along a soil fertility gradient in a Neotropical savanna. Aust. J. Bot. 59, 274-282.

Belsky, A.J., 1994. Influences of trees on savanna productivity: tests of shade, nutrients, and tree-grass competition. Ecology 75, 922-932.

Bieras, A.C., Sajo, M.G., 2009. Leaf structure of the cerrado (Brazilian savanna) woody plants. Trees 23, 451-471.

Brudvig, L.A., 2010. Woody encroachment removal from Midwestern oak savannas alters understory diversity across space and time. Rest. Ecol. 18, 74-84.

Chazdon, R.L., Pearcy, R.W., 1986. Photosynthetic responses to light variation in rainforest species. Oecologia 69, 524-531.

Denslow, J.S., Guzman, G., 2000. Variation in stand structure, light and seedling abundance across a tropical moist forest chronosequence. Panama. J. Veg. Sci. 11, 201-212.

Durigan, G., Ratter, J.A., 2006. Successional changes in cerrado and cerrado/forest ecotonal vegetation in western São Paulo State, Brazil, 1962-2000. Edinburgh J. Bot. 63, 119-130.

Durigan, G., Ratter, J.A., 2016. The need for a consistent fire policy for Cerrado conservation. J. Appl. Ecol. 53, 11-15.

Eldridge, D.J., Bowker, M.A., Maestre, F.T., Roger, E., Reynolds, J.F., Whitford, W.G., 2011. Impacts of shrub encroachment on ecosystem structure and functioning: towards a global synthesis. Ecol. Lett. 14, 709-722.

Franco, A.C., Lüttge, U., 2002. Midday depression in savanna trees: coordinated adjustments in photochemical efficiency, photorespiration, $\mathrm{CO}_{2}$ assimilation and water use efficiency. Oecologia 131, 356-365.

Franco, A.C., Matsubara, S., Orthen, B., 2007. Photoinhibition, carotenoid composition and the co-regulation of photochemical and non-photochemical quenching in neotropical savanna trees. Tree Phys. 27, 717-725.

Franco, A.C., Rossatto, D.R., Silva, L.C.R., Ferreira, C.S., 2014. Cerrado vegetation and global change: the role of functional types: resource availability and disturbance in regulating plant community responses to rising $\mathrm{CO}_{2}$ levels and climate warming. Theor. Exp. Plant Phys. 26, 19-38.

Givnish, T.J., Montgomery, R.A., Goldstein, G., 2004. Adaptive radiation of photosynthetic physiology in the Hawaiian lobeliads: light regimes, static light responses, and whole-plant compensation points. Am. J. Bot. 91, 228-246.

Givnish, T.J., 1988. Adaptation to sun and shade: a whole-plant perspective. Funct. Plant Biol. 15, 63-92.

Goulart, M.F., Lovato, M.B., de Vasconcellos Barros, F., Valladares, F., Lemos-Filho, J.P., 2011. Which extent is plasticity to light involved in the ecotypic differentiation of a tree species from savanna and forest? Biotropica 43, 695-703.

Govender, N., Trollope, W.S., Van Wilgen, B.W., 2006. The effect of fire season, fire frequency, rainfall and management on fire intensity in savanna vegetation in South Africa. J. Appl. Ecol. 43, 748-758.

Hoffmann, W.A., da Silva Jr, E.R., Machado, G.C., Bucci, S.J., Scholz, F.G., Goldstein, G., Meinzer, F.C., 2005. Seasonal leaf dynamics across a tree density gradient in a Brazilian savanna. Oecologia 145, 306-315.

Hoffmann, W.A., Geiger, E.L., Gotsch, S., Rossatto, D.R., Silva, L.C.R., Lau, O.L., Haridasan, M., Franco, A.C., 2012a. Ecological thresholds at the savanna-forest boundary: how plant traits, resources and fire govern the distribution of tropical biomes. Ecol. Lett. 15, 759-768.

Hoffmann, W.A., Jaconis, S.Y., McKinley, K.L., Geiger, E.L., Gotsch, S.G., Franco, A.C. 2012 b. Fuels or microclimate? Understanding the drivers of fire feedbacks at savanna-forest boundaries. Austral Ecol. 37, 634-643.

Kitajima, K., 1994. Relative importance of photosynthetic traits and allocation patterns as correlates of seedling shade tolerance of 13 tropical trees. Oecologia 98, 419-428.

Kotowski, W., Diggelen, R., 2004. Light as an environmental filter in fen vegetation. J. Veg. Sci. 15, 583-594.

Lüttge, U., 2008. Physiological Ecology of Tropical Plants, 2nd edition. Springer-Verlag, Berlin Heidelberg.

Lemenih, M., Gidyelew, T., Teketay, D., 2004. Effects of canopy cover and understory environment of tree plantations on richness: density and size of colonizing woody species in southern Ethiopia. Forest Ecol. Manag. 194, 1-10.

Lemos Filho, J.P.D., Goulart, M.F., Lovato, M.B., 2008. Populational approach in ecophysiological studies: the case of Plathymenia reticulata, a tree from Cerrado and Atlantic Forest. Braz. J. Plant Phys. 20, 205-216.

Lobo, F.D.A., De Barros, M.P., Dalmagro, H.J., Dalmolin, A.C., Pereira, W.E., de Souza, É.C., Vourlitis, G.L., Ortíz, C.R., 2013. Fitting net photosynthetic light-response curves with Microsoft Excel—a critical look at the models. Photosynthetica 51, 445-456.

Ludwig, F., de Kroon, H., Berendse, F., Prins, H.H., 2004. The influence of savanna trees on nutrient, water and light availability and the understorey vegetation. Plant Ecol. 170, 93-105.

McGuire, J.P., Mitchell, R.J., Moser, E.B., Pecot, S.D., Gjerstad, D.H., Hedman, C.W., 2001. Gaps in a gappy forest: plant resources, longleaf pine regeneration, and understory response to tree removal in longleaf pine savannas. Can. J. For. Res. 31, 765-778.

Mendonça, R.C., Felfili, J.M., Walter, B.M.T., Silva-Júnior, M.C., Rezende, A.B., Filgueiras, T.S., Nogueira, P.E., Fagg, C.W., 2008. Flora vascular do bioma cerrado: checklist com12.356 espécies. In: In: Sano, S.M., Almeida, S.P., Ribeiro, J.F. (Eds.), (Org.) Cerrado: Ecologia E Flora, vol. 2. Embrapa Cerrados, Brasília, pp. 213-228.

Murphy, B.P., Bowman, D.M., 2012. What controls the distribution of tropical forest and savanna? Ecol. Lett. 15, 748-758.

Peterson, D.W., Reich, P.B., Wrage, K.J., 2007. Plant functional group responses to fire frequency and tree canopy cover gradients in oak savannas and woodlands. J. Veg. Sci. 18, 3-12.

Pinheiro, E.S., Durigan, G., 2009. Dinâmica espaço-temporal (1962-2006) das fitofisionomias em unidade de conservação do cerrado no sudeste do Brasil. Rev. Bras. Bot. $32,441-454$.

Pinheiro, L.F.S., Kolb, R.M., Rossatto, D.R., 2016. Changes in irradiance and soil properties explain why typical non-arboreal savanna species disappear under tree encroachment. Aust. J. Bot. 64, 333-341.

Pinheiro, L.F.S., Kolb, R.M., Rossatto, D.R., 2017. Leaf anatomical traits of non-arboreal savanna species along a gradient of tree encroachment. Acta Bot. Bras. http://dx.doi. org/10.1590/0102-33062017abb0280.

Poorter, L., Bongers, F., 2006. Leaf traits are good predictors of plant performance across 53 rain forest species. Ecology 87, 1733-1743.

Poorter, L., Kitajima, K., 2007. Carbohydrate storage and light requirements of tropical moist and dry forest tree species. Ecology 88, 1000-1011.

Poorter, L., 1999. Growth responses of 15 rain-forest tree species to a light gradient: the relative importance of morphological and physiological traits. Funct. Ecol. 13, $396-410$.

Poorter, L., 2009. Leaf traits show different relationships with shade tolerance in moist versus dry tropical forests. New Phytol. 181, 890-900.

Porra, R.J., Thompson, W.A., Kriedemann, P.E., 1989. Determination of accurate extinction coefficients and simultaneous equations for assaying chlorophylls a and b extracted with four different solvents: verification of the concentration of chlorophyll standards by atomic absorption spectroscopy. Biochim. Biophys. Acta-Bioenerg. 975, 384-394.

Prior, L.D., Eamus, D., Bowman, D.M.J.S., 2003. Leaf attributes in the seasonally dry 
tropics: a comparison of four habitats in northern Australia. Funct. Ecol. 17, 504-515. Prioul, J.L., Chartier, P., 1977. Partitioning of transfer and carboxylation components of intracellular resistance to photosynthetic $\mathrm{CO}_{2}$ fixation: a critical analysis of the methods used. Ann. Bot. 41, 789-800.

Rossatto, D.R., Rigobelo, E.C., 2016. Tree encroachment into savannas alters soil microbiological and chemical properties facilitating forest expansion. J. For. Res. 27, 1047-1054.

Santiago, L.S., Wright, S.J., 2007. Leaf functional traits of tropical forest plants in relation to growth form. Funct. Ecol. 21, 19-27.

Scholes, R.J., Archer, S.R., 1997. Tree-grass interactions in savannas. Annu. Rev. Ecol. Syst. 28, 517-544.

Silva, L.C., Sternberg, L., Haridasan, M., Hoffmann, W.A., Miralles-Wilhelm, F., Franco, A.C., 2008. Expansion of gallery forests into central Brazilian savannas. Glob. Change Biol. 14, 2108-2118.

Stevens, N., Lehmann, C.E., Murphy, B.P., Durigan, G., 2017. Savanna woody encroachment is widespread across three continents. Glob. Change Biol. 23, 235-244.

Thompson, W.A., Huang, L.K., Kriedemann, P.E., 1992. Photosynthetic response to light and nutrients in sun-tolerant and shade-tolerant rainforest trees II. Leaf gas exchange and component processes of photosynthesis. Funct. Plant Biol. 19, 19-42.
Thornley, J.H.M., 1976. Mathematical Models in Plant Physiology. Academic Press, London.

Valladares, F., Niinemets, U., 2008. Shade tolerance, a key plant feature of complex nature and consequences. Annu. Rev. Ecol. Syst. 39, 237-257.

Valladares, F., Martinéz-Ferri, E.L.S.A., Balaguer, L., Pérez-Corona, E., Manrique, E., 2000. Low leaf-level response to light and nutrients in Mediterranean evergreen oaks: a conservative resource-use strategy. New Phytol. 148, 79-91.

Valladares, F., Skillman, J.B., Pearcy, R.W., 2002. Convergence in light capture efficiencies among tropical forest understory plants with contrasting crown architectures: a case of morphological compensation. Am. J. Bot. 89, 1275-1284.

Valladares, F., García-Plazaola, J.I., Morales, F., Niinemets, U., 2012. Photosynthetic responses to radiation. In: Flexas, J., Loreto, F., Medrano, H. (Eds.), Ecophysiology of Photosynthesis in Terrestrial Higher Plants. Cambridge University Press, Cambridge, pp. 243-260.

Walters, M.B., Reich, P.B., 1996. Are shade tolerance, survival, and growth linked? Low light and nitrogen effects on hardwood seedlings. Ecology 77, 841-853.

Wellburn, A.R., 1994. The spectral determination of chlorophylls a and b, as well as total carotenoids, using various solvents with spectrophotometers of different resolution. J. Plant Phys. 144, 307-313. 